\title{
VIEWPOINT
}

\section{Land access policy incentives: Emerging approaches to transitioning farmland to a new generation}

\author{
Julia C. D. Valliant ${ }^{a} *$ \\ Indiana University \\ Julia Freedgood b \\ American Farmland Trust
}

Submitted August 26, 2019 / Revised November 27, 2019 / Accepted December 2, 2019 /

Published online May 15, 2020

Citation: Valliant, J. C. D., \& Freedgood, J. (2020). Land access policy incentives: Emerging approaches to transitioning farmland to a new generation. Journal of Agriculture, Food Systems, and Community Development, 9(3), 71-78. https://doi.org/10.5304/jafscd.2020.093.027

Copyright (C) 2020 by the Authors. Published by the Lyson Center for Civic Agriculture and Food Systems. Open access under CC-BY license.

\begin{abstract}
Success for young, beginning, and/or socially disadvantaged (New Gen) farmers and ranchers depends on their ability to secure suitable land to start and expand their operations. Yet this is a significant and widely reported challenge. It is especially difficult for beginners to acquire suitable land with appropriate housing and infrastructure.

The U.S. federal government and several states have recognized this challenge and addressed it with various types of financial incentive policies. However, little research has been done to measure the impacts and reach of these policies, even though the biggest of them have a decade of

a * Corresponding author: Julia C. D. Valliant, The Ostrom Workshop; Indiana University; 515 North Park Avenue; Bloomington, Indiana 47408 USA; +1-812-856-5029; jdv@indiana.edu

b Julia Freedgood, American Farmland Trust; One Short Street \#2; Northampton, Massachusetts 01060 USA; +1-413-586-

9330, extension 11; jfreedgood@,farmland.org
\end{abstract}

experience, increasing participation, and investment totaling over US $\$ 210$ million. In this viewpoint, we first introduce the slim evidence that exists of the impacts and reach of land access policy incentive (LAPI) programs. Next, we call for further assessment of three major types of LAPIs. At the state level, these include (1) beginning farmer tax credits and (2) easement incentives to help New Gen farmers buy and preserve farmland. At the federal level, we include the Conservation Reserve Program-Transition Incentives Program (CRP-TIP) of the U.S. Department of Agriculture's

\section{Funding Disclosure}

This material is based upon work that was supported by the National Institute of Food and Agriculture, U.S. Department of Agriculture, under award number 2016-38640-25381 through the North Central Region SARE program under project number LNC16-377. USDA is an equal opportunity employer and service provider. Any opinions, findings, conclusions, or recommendations expressed in this publication are those of the authors and do not necessarily reflect the view of the U.S. Department of Agriculture. 
Farm Service Agency. The purpose of evaluation will be to understand more about whom LAPI programs help, what effects they have, and what recommendations can be made to strengthen policy design and program delivery.

\section{Keywords}

Beginning Farmers/Ranchers, Conservation, Farm/Ranch Owner, Farm/Ranch Transfer, Federal Policy, Land Access, Policy Assessment, Policy Brief, Socially Disadvantaged

Farmers/Ranchers, State Policy

\section{Introduction}

Success for new farmers and ranchers depends on their ability to secure suitable land to start and expand their operations. Since most do not inherit their land (Katchova \& Ahearn, 2016), they face significant financial and socio-cultural obstacles to buying or leasing any (Inwood, 2013). Therefore, land access is significant challenge, as American Farmland Trust (AFT) (Freedgood \& Dempsey, 2014), the Council on Food, Agricultural and Resource Economics (C-FARE; 2017) and many others from the U.S. Department of Agriculture (USDA)'s Economic Research Service (Ahearn, 2013) to the National Young Farmers Coalition (Ackoff, Bahrenburg, \& Shute, 2017) widely report. Mostly managing small operations, new farmers face long odds (Ruhf, 2013) given farm consolidation (MacDonald, Hoppe, \& Newton, 2018), rapid appreciation of land values (Key \& Burns, 2018), conversion of agricultural lands to development (Sorensen, Freedgood, Dempsey, \& Theobald, 2018; USDA Natural Resources Conservation Service [NRCS], 2018), and a tight supply of available land to rent or to purchase. As an indication of tight supply, the USDA estimated that while $10 \%$ of agricultural lands would change ownership between 2015 and 2019, only 2\% would be on the open market (USDA National Agricultural Statistics Service [NASS], 2015), leaving 98\% of agricultural lands inaccessible to nonfamily members. These factors converge to favor large farms, family members, and established operators at the expense of New Gen farmers (Burns, Key, Tulman, Borchers, \& Weber, 2018).

Unequal access plays out in the numbers, both in terms of access to participation in agriculture and access to ownership. More than six times as many primary producers are age 65 and older as those under age 35 (USDA NASS, 2019a), which stands in stark contrast to the general workforce, where more than six times as many people under age 35 are employed as those over age 65 (Bigelow, Borchers, \& Hubbs, 2016). Further, more than $69 \%$ of the agricultural land owned by nonoperator landlords is owned by seniors aged 65 and older (Bigelow et al., 2016). Pairing these numbers illustrates the urgent need for policy interventions to facilitate younger producers' access to participation and ownership, through land transfer and land access for new farmers and ranchers.

\section{Policy Responses to the Scope of the Problem}

Recognizing this need, the federal government and several states have created a variety of financial incentive programs. While their approaches differ, their motivations are similar: to revitalize rural communities (Hamilton, 2011; Meuleners, 2013) and to catalyze land transfers to new producerswhether they are descendants of multigenerational farm families or first-generation farmers and ranchers (Carolan, 2018; Clark, Inwood, \& Sharp, 2012). The incentive programs define new producers according to how long they have farmed or ranched, and/or their net worth or age. Some incentives also aim to facilitate access for entering farmers and ranchers who are from racial and ethnic groups that have traditionally experienced discrimination in the U.S. (USDA Farm Service Agency [FSA], 2019b). To focus our analysis on the policy incentives and the producers whose land access they prioritize, we use the term "New Gen" to refer to young, beginning, and/or socially disadvantaged farmers and ranchers.

Interest in these financial incentive programs is growing rapidly. In 2017, both the Maryland Next Gen Farmland Acquisition Program and the Minnesota Beginning Farmer Tax Credit (BFTC) were passed into law. After its first eight months, the Minnesota program had received 300 complete applications (M. McDevitt, personal correspondence, September 13, 2018), suggesting pent-up demand. These numbers add to the state's 37,000 
acres $(15,000$ hectares) enrolled in the Conservation Reserve Program-Transition Incentive Program (CRP-TIP) of the USDA Farm Service Agency, through which 326 more owners are transferring operations and/or land to New Gen farmers. Notably, Minnesota's BFTC managers observe almost no overlap in participation between the two programs (M. McDevitt, personal correspondence, May 30, 2019). Since 2017, two additional states have proposed (Ohio, Oregon) and three have even passed (Colorado, Kentucky, Pennsylvania) incentives of their own, and the 2018 farm bill increased CRP-TIP funding to US $\$ 50$ million, from $\$ 25$ million in 2008 and $\$ 33$ million in 2014 (National Sustainable Agriculture Coalition, 2014). Meanwhile, participation in the longerstanding BFTC programs has accelerated: Iowa's numbers nearly tripled from 2013 to 2017 (S. Ferguson, personal communication, September 19, 2018), and applications to Nebraska's program have increased six-fold since 2008 (Beck, Carter, \& Circo, 2018).

Despite the upsurge of interest in financial incentive policies, little is known about their characteristics, impacts, and reach (Schilling, Esseks, Duke, Gottlieb, \& Lynch, 2015; Valliant, Ruhf, Gibson, Brooks, \& Farmer, 2019). Given the critical need to facilitate land transition and access to land, it is our view that these policies should be assessed together as a body of Land Access Policy Incentives (LAPIs). In addition to an assessment, we believe there is a need to build a community of practice to examine, improve, and advance them, starting with three major types of LAPIs (presented in Table 1). These categories are the highest prior- ity because the federal and state governments have awarded them over US $\$ 210$ million in funding but have conducted little evaluation.

Two approaches to LAPIs compensate landowners for choosing a New Gen farmer as the farm's next operator or buyer. These include BFTCs in three Midwestern states and the federal CRP-TIP program. Through state-level BFTC programs, landowners earn a credit on their state income taxes. Through CRP-TIP, landowners with expiring CRP contracts earn two additional years of payments in exchange for renting or selling their land to a New Gen farmer (USDA FSA, 2019b). The third type of LAPI program provides financing to the Next Gen farmer directly; two state agricultural easement incentive programs in the Mid-Atlantic region have helped 53 young and beginning farmers obtain financing to purchase and protect high-quality farmland. Here we do not address incentives that some counties or localities offer, private mechanisms, and a longstanding federal-state incentive, the Aggie Bond, which serves mainly banks and other lenders that provide credit to New Gen farmers and ranchers (Williamson \& Katchova, 2013).

LAPIs' participation numbers stand out among a range of mechanisms that aim to facilitate land transition and access. Related policy and programmatic interventions such as Land Link programs often attract very few landowners with agricultural assets to transfer, sometimes too few for the programs to function (Hersey \& Adams, 2017; Ruhf, Jaffe, Cosgrove, \& Eliot, 2012; Valliant et al., 2019). LAPIs appear to be an exception. Yet while participation is high in some places, utilization is

Table 1. Classes of Land Access Policy Incentives (LAPIs)

\begin{tabular}{lll}
\hline Policy level & \multicolumn{1}{c}{ Policy name } & \multicolumn{1}{c}{ Incentive mechanism } \\
\hline $\begin{array}{l}\text { State } \\
\left(\mathrm{IA}, \mathrm{KY} \mathrm{H}^{*}, \mathrm{MN}, \mathrm{NE}\right)\end{array}$ & Beginning Farmer Tax Credit (BFTC) & $\begin{array}{l}\text { Generally, owners who choose a beginning farmer as their next } \\
\text { operator or buyer earn a credit on state income taxes. }\end{array}$ \\
\hline $\begin{array}{l}\text { State } \\
\left(\mathrm{DE}, \mathrm{MD}, \mathrm{PA}^{*}\right)\end{array}$ & $\begin{array}{l}\text { Next Gen and Young Farmer } \\
\text { Easement Incentives }\end{array}$ & $\begin{array}{l}\text { The state provides financing to help young or beginning farmers } \\
\text { purchase land and protect it with an agricultural conservation } \\
\text { easement. }\end{array}$ \\
\hline Federal & $\begin{array}{l}\text { Conservation Reserve Program- } \\
\text { Transition Incentives Program } \\
(\text { CRP-TIP) }\end{array}$ & $\begin{array}{l}\text { An owner whose land is expiring out of CRP earns two additional } \\
\text { years of payments upon choosing a beginning or socially } \\
\text { disadvantaged farmer as the land's next operator or buyer. }\end{array}$ \\
\hline
\end{tabular}

* New LAPI programs as of 2019-2020 
uneven. BFTCs typically use less than the full tax credits allocated to them on an annual basis (Tidgren, 2017). CRP-TIP is well used in some states, but half the states have had no participation at all (USDA FSA, 2019a). Table 2 presents the range of participation numbers by state.

Analyses of barriers to land access and farm/ ranch transfer (Valliant et al., 2020) and policy responses often call for more states to emulate existing state LAPI policies (Ackoff et al., 2017; Meuleners, 2013) and for the federal government to continue to expand investment in CRP-TIP (Calo \& Petersen-Rockney, 2018; Slack, 2013). The USDA Advisory Committee on Beginning Farmers and Ranchers Land Tenure Subcommittee (2015) similarly recommended a scale-up of state-level LAPIs to the federal level. LAPIs win these endorsements because of their promise to stimulate owners to lease or sell their operations to New Gen farmers and ranchers, and thereby encourage new family farms and new rural enterprise (e.g., National Farmers Union, 2019). However, these calls to replicate and expand existing LAPIs are issued in a virtual vacuum of evidence of the incentives' effects.

Of the three types of LAPIs, the only research has been conducted on BFTCs and one four-state assessment of the national CRP-TIP (Johnson, 2017). Building on this early research, which suggested slight positive effects on beginning farm prevalence (Williamson \& Girardi, 2016) and beginning farmers' persistence in farming (Girardi, 2015), the next step is to understand more about who the LAPI programs help, what impacts they have had, and what recommendations can be made from these findings to strengthen program design and delivery to achieve higher returns for diverse New Gen farmers, landowners, and rural communities.

\section{The Intended Effects of LAPIs}

The ability of a New Gen producer to enter and succeed in agriculture is vital to the economic and social health of rural communities, and these are the outcomes the LAPIs ultimately aim to foster. Not only are there positive relationships between New Gen participation in agriculture and economic outcomes (Lobley \& Baker, 2012; Zagata \& Sutherland, 2015), but also farms that anticipate New Gen leadership perform better than those without such plans (Chiswell, 2014; Inwood \& Sharp, 2012). Secondly, New Gen farmers make an outsized contribution to sustainable agriculture and food systems, being responsible for more than their share of certified organic and direct-toconsumer sales (USDA NASS, 2014).

Landowners face tax and other policy disincentives to transferring their land and operations, and even more so to an unrelated New Gen farmer. They also face personal, economic, and emotional barriers. The result of these forces is that they often delay transitioning ownership until death (Advisory Committee on Beginning Farmers and Ranchers, 2015; Leonard, Kinsella, O’Donoghue,
Table 2. Approximate Numbers of Incentive Contracts by State and Class of Land Access Policy Incentive (LAPI)

\section{LAPIs}

(Number of unique, cumulative contracts as of 2019/2020)

\begin{tabular}{lrrrr}
\hline LAPI & BFTC/D & Easement & CRP-TIP & Total \\
\hline Colorado* & 0 & $\sim$ & 54 & 54 \\
\hline Delaware & $\sim$ & 35 & 0 & 36 \\
\hline lowa & 2,957 & $\sim$ & 127 & 3,084 \\
\hline Maryland & $\sim$ & 18 & 0 & 18 \\
\hline Minnesota & 912 & $\sim$ & 326 & 1,238 \\
\hline Missouri & $\sim$ & $\sim$ & 79 & 79 \\
\hline Montana* & 0 & $\sim$ & 218 & 218 \\
\hline Nebraska & 439 & $\sim$ & 132 & 571 \\
\hline North Dakota & $\sim$ & $\sim$ & 210 & 210 \\
\hline Oregon & $\sim$ & $\sim$ & 45 & 45 \\
\hline Washington & $\sim$ & $\sim$ & 109 & 109 \\
\hline Others & $\sim$ & $\sim$ & $0-25$ & $\mathbf{5 , 8 8 1}$ \\
\hline
\end{tabular}

Sources: Beary, personal communication, July 12, 2019; Beck et al., 2018; McDevitt, personal correspondence, June 25, 2019; McHenry, personal correspondence, April 20, 2020; USDA FSA, 2019a.

* Colorado and Montana technically have Beginning Farmer/Rancher Tax Deduction incentive policies, but they have attracted no participation (W. Anseth, personal communication, July 11, 2019; J. Rubingh, personal correspondence, May 23, 2019). 
Farrell, \& Mahon, 2017; Mishra, Durst, \& El-Osta, 2005). If they do hand over the reins during their lifetimes, they typically choose an heir or a wellestablished producer (Goeller, 2001; Ruhf, 2013). These two common patterns-delay and transferring to an established farmer-impede access to land for New Gen farmers.

LAPIs aim to shift owners' decisions to create access for New Gen producers by addressing the economics of this problem. They also seek to improve equity in land access and rural sustainability. For example, CRP-TIP compensates owners who lease or transfer to a socially disadvantaged farmer (Key \& Lyons, 2019), referring to women and farmers of races and ethnicities that have faced discrimination (Horst \& Marion, 2019). These include African American farmers, who, after systematic and well-documented dispossession of lands (Horst, 2019), now make up less than $2 \%$ of farmers, as well as the growing population of Latinx farmers, who make up about 3\% (USDA NASS, 2019b). Even though people of color make up $26 \%$ of the U.S. population and $62 \%$ of farm laborers, only $3 \%$ of agricultural landowners are people of color (Horst \& Marion, 2019). Women, half the population, make up only $24 \%$ of agricultural landowners. However, despite being designed to improve equity for underserved populations, an analysis of CRP-TIP in four states found that none of these states' approximately $480 \mathrm{New}$ Gen participants were socially disadvantaged farmers (Johnson, 2017). Understanding the reasons for this failure and ways to remedy it is another reason an assessment of these policies and their implementation is so timely and essential.

\section{Conclusions and Recommendations}

Iowa, Minnesota, and Nebraska have invested more than US $\$ 89$ million in tax credits to entice farm and ranch landowners to choose New Gen operators and transferees. Delaware and Maryland have invested US $\$ 13$ million in land purchases by New Gen farmers. Between the 2008 and 2018 farm bills, the U.S. government will have invested over US $\$ 108$ million in CRP-TIP, even though this program has undergone no evaluation. Despite this level of investment in the programs, the participation patterns we have presented reveal critical gaps about the impacts and effectiveness of the more than US $\$ 210$ million invested in LAPIs. To address these gaps, the following questions must be addressed using coordinated sets of mixed and transdisciplinary methods led by researchers in partnership with service providers, and supported, informed, and mutually enriched by a national community of practice:

- Who do LAPI programs help, e.g., what kinds of farms and ranches, farmers and ranchers, and owners, and on what scale?

- What are the patterns of participation and nonparticipation, and what explains them?

- What impacts have LAPIs had, e.g., to what extent and how do they affect landowners' and New Gen farmers and ranchers' interactions and decisions?

- What are the main barriers to outreach and implementation of LAPIs?

- How and to what extent do LAPIs facilitate access to land by New Gen farmers and ranchers, and how can LAPIs' structures and implementation better reach this goal?

Assessment is needed to investigate the utilization and impacts of these programs, explore participant motivations, and determine what is working and what is not. The results will characterize the efficaciousness of the incentives and suggest revisions to improve them. This contribution will ultimately support policy and decision-makers, as well as funders and investors, in crafting and delivering policy support for land transfers, Next Generation agriculture, agricultural communities, and rural-urban interdependence.

\section{Acknowledgments}

The authors wish to acknowledge the leaders of the country's land access policy incentive programs for generously sharing their experiences and insight. In addition, a team of national advisors helped to guide this research; particular thanks to Kathy Ruhf, Mary Fund, Wyatt Fraas, Kevin Gibson, and Maria Marshall. Many thanks as well to Suzanna Denison, Cris Coffin, Dan Knudsen, Analena Bruce, Amalie Lipstreu, and James Farmer for reviewing parts of this policy brief in draft form. 


\section{References}

Ackoff, S., Bahrenburg, A., \& Shute, L. L. (2017). Building a future with farmers II: Results and recommendations from the National Young Farmer Survey. Retrieved from National Young Farmers Coalition website: https://www.youngfarmers.org/resource/building-a-future-with-farmers-ii/

Advisory Committee on Beginning Farmers and Ranchers. (2015). Land tenure, access, and farm business transitions for beginning farmers and ranchers: Recommendations from the Advisory Committee on Beginning Farmers and Ranchers. Retrieved from the U.S. Department of Agriculture [no longer available online].

Ahearn, M. (2013). Beginning farmers and ranchers at a glance (Economic Brief No. EB-22). Retrieved from the U.S. Department of Agriculture Economic Research Service website: https://www.ers.usda.gov/publications/pub-details/?pubid $=42876$

Beck, C., Carter, M., \& Circo, A. (2018). The Beginning Farmer Tax Credit Act: Performance on selected metrics. Retrieved from Performance Audit Committee, Legislative Audit Office, Nebraska Legislature website: https://nebraskalegislature.gov/pdf/reports/audit/begfarm 2018.pdf

Bigelow, D., Borchers, A., \& Hubbs, T. (2016). U.S. farmland ownership, tenure, and transfer. Washington, D.C.: U.S. Department of Agriculture Economic Research Service. Retrieved from https://www.ers.usda.gov/publications/pub-details/?pubid=74675

Burns, C., Key, N., Tulman, S., Borchers, A., \& Weber, J. (2018). Farmland values, land ownership, and returns to farmland, 2000-2016 (Report No. ERR-245). Washington, D.C.: U.S. Department of Agriculture Economic Research Service. Retrieved from https://www.ers.usda.gov/publications/pub-details/?pubid $=87523$

Calo, A., \& Petersen-Rockney, M. (2018). What beginning farmers need most in the next farm bill: Land. Retrieved from Berkeley Food Institute, University of California-Berkeley website: https:// food.berkeley.edu/wp-content/uploads/2018/08/BFI-Beginning-Farmers-Policy-Brief.pdf

Carolan, M. (2018). Land changing hands: Experiences of succession and farm (knowledge) acquisition among firstgeneration, multigenerational, and aspiring farmers. Land Use Policy, 79, 179-189. https://doi.org/10.1016/j.landusepol.2018.08.011

Chiswell, H. M. (2014). The importance of next generation farmers: A conceptal framework to bring the potential successor into focus. Geography Compass, 8(5), 300-312. https://doi.org/10.1111/gec3.12131

Clark, J. K., Inwood, S., \& Sharp, J. S. (2012). Local food systems: The birth of new farmers and the demise of the family farm? In J. D. Gatrell \& P. S. Ross (Eds.), Local Food Systems in Old Industrial Regions: Concepts, Spatial Context, and Local Practices (pp. 131-146). London \& New York: Routledge. https://doi.org/10.4324/9781315592855

Council on Food, Agricultural and Resource Economics (C-FARE). (2017). Agriculture and applied economics priorities and solutions. Retrieved from https://www.cfare.org/s/PrioritiesandSolutionsReport04-06-2017-LOW v22.pdf

Freedgood, J., \& Dempsey, J. (2014). Cultivating the next generation: Resources and policies to belp beginning farmers succeed in agriculture. Retrieved from American Farmland Trust website: https://farmlandinfo.org/publications/cultivatingthe-next-generation-resources-and-policies-to-help-beginning-farmers-succeed-in-agriculture/

Girardi, A. G. (2015). Beginning Farmer Tax Credit Program: Tax credit program evaluation study. Retrieved from Iowa Department of Revenue, Des Moines, website: https://www.legis.iowa.gov/docs/publications/DF/755564.pdf

Goeller, D. (2001). Successful farm business transitions. Cornhusker Economics, 7. Retrieved from https://digitalcommons.unl.edu/agecon_cornhusker/7

Hamilton, N. D. (2011). America's new agrarians: Policy opportunities and legal innovations to support new farmers. Fordham Environmental Law Review, 22(3), 523-562. https:/ ir.lawnet.fordham.edu/elr/

Hersey, A., \& Adams, M. (2017). Using contribution analysis to assess the influence of farm link programs in the U.S. Journal of Agriculture, Food Systems, and Community Development, 7(3), 83-103. https://doi.org/10.5304/jafscd.2017.073.006

Horst, M. (2019). New Research Explores the Ongoing Impact of Racism on the U.S. Farming Landscape. Retrieved from https://civileats.com/2019/01/25/new-research-explores-the-ongoing-impact-of-racism-on-the-u-s-farminglandscape/ 
Horst, M., \& Marion, A. (2019). Racial, ethnic and gender inequities in farmland ownership and farming in the U.S. Agriculture and Human V alues, 36(1), 1-16. https://doi.org/10.1007/s10460-018-9883-3

Inwood, S. M. (2013). Social forces and cultural factors influencing farm transition. Choices, 28(2), 1-5. Retrieved from http://www.choicesmagazine.org/choices-magazine/theme-articles/transitions-in-agriculture/social-forces-andcultural-factors-influencing-farm-transition

Inwood, S. M., \& Sharp, J. S. (2012). Farm persistence and adaptation at the rural-urban interface: Succession and farm adjustment. Journal of Rural Studies, 28, 107-117. https://doi.org/10.1016/j.jrurstud.2011.07.005

Johnson, A. (2017). Pathways to land access: A study of the Conservation Reserve Program-Transition Incentives Program in four states. Retrieved from Center for Rural Affairs, Lyons, Nebraska: https://www.cfra.org/pathways-to-land-access

Katchova, A. L., \& Ahearn, M. C. (2015). Dynamics of farmland ownership and leasing: Implications for young and beginning farmers. Applied Economic Perspectives and Policy, 38(2), 334-350. https://doi.org/10.1093/aepp/ppv024

Key, N., \& Burns, C. (2018). Changing farmland values affect renters and landowners differently. Washington, DC: U.S. Department of Agriculture Economic Research Service. Retrieved from https://www.ers.usda.gov/amberwaves/2018/januaryfebruary/changing-farmland-values-affect-renters-and-landowners-differently/

Key, N., \& Lyons, G. (2019). An overview of beginning farms and farmers. Washington, D.C.: U.S. Department of Agriculture, Economic Research Service. Retrieved from https://www.ers.usda.gov/publications/pub-details/?pubid=95009

Leonard, B., Kinsella, A., O’Donoghue, C., Farrell, M., \& Mahon, M. (2017). Policy drivers of farm succession and inheritance. Land Use Policy, 61 147-159. https://doi.org/10.1016/j.landusepol.2016.09.006

Lobley, M., \& Baker, J. R. (2012). Succession and retirement in family farm businesses. In M. Lobley, J. R. Baker, \& I. Whitehead (Eds.), Keeping it in the family: International perspectives on succession and retirement on family farms (1-20). Farnham, UK: Ashgate. https://doi.org/10.4324/9781315591001

MacDonald, J. M., Hoppe, R. A., \& Newton, D. (2018). Three Decades of Consolidation in U.S. Agriculture. Washington, D.C.: U.S. Department of Agriculture Economic Research Service. Retrieved from https://www.ers.usda.gov/webdocs/publications/88057/eib-189.pdf

Meuleners, A. (2013). Finding fields: Opportunities to facilitate and incentivize the transfer of agricultural property to new and beginning farmers. Drake Journal of Agricultural Law, 18(1), 211-238. https:/ /aglawjournal.wp.drake.edu/

Mishra, A. K., Durst, R., \& El-Osta, H. S. (2005, April 1). How do U.S. farmers plan for retirement? Amber Waves. Retrieved from https://www.ers.usda.gov/amber-waves/2005/april/how-do-us-farmers-plan-for-retirement/

National Farmers Union. (2019, March). Policy of the National Farmers Union. Declaration from the National Farmers Union 117th Anniversary Convention, Bellevue, Washington. Retrieved from https://1yd7z7koz052nb8r33cfxyw5wpengine.netdna-ssl.com/wp-content/uploads/2019/04/2019-NFU-Policy-Book.pdf

National Sustainable Agriculture Coalition. (2014). 2014 farm bill drill down: Beginning and socially disadvantaged farmers. Retrieved from https://sustainableagriculture.net/blog/2014-drilldown-bfr-sda/

Paine, L., \& Sullivan, A. (2014). Beginning farmers in Wisconsin: 2014 survey summary. Retrieved from State of Wisconsin Department of Agriculture, Trade and Consumer Protection, Madison, website [no longer available online].

Ruhf, K. Z. (2013). Access to farmland: A systems change perspective. Journal of Agriculture, Food Systems, and Community Development, 4(1), 51-60. https://doi.org/10.5304/jafscd.2013.041.006

Ruhf, K., Jaffe, J., Cosgrove, J., \& Eliot, A. (2012). Successful farm transfer planning for farmers without an identified successor. Retrieved from Land For Good website: https://landforgood.org/wp-content/uploads/LFG-Farm-TransferPlanning-Without-An-Identified-Successor-Handbook.pdf

Schilling, B. J., Esseks, J. D., Duke, J. M., Gottlieb, P. D., \& Lynch, L. (2015). The future of preserved farmland: Ownership succession in three mid-Atlantic states. Journal of Agriculture, Food Systems, and Community Development, 5(2), 129-153. https://doi.org/10.5304/jafscd.2015.052.008

Slack, T. (2013). Challenges facing elder farmers and the need for a nationwide Farm-On program. Elder Law Journal, 20, 485-520. Retrieved from https://theelderlawjournal.com/archives/

Sorensen, A. A., Freedgood, J., Dempsey, J., \& Theobald, D. M. (2018). Farms under threat: The state of America's farmland. Retrieved from the Farmland Information Center website: https://www.farmlandinfo.org/farms-under-threat-state-americas-farmland 
Tidgren, K. A. (2017). 2018 ushers in cuts to Iowa Beginning Farmer Tax Credit Program. Retrieved from Iowa State University Center for Agricultural Law and Taxation website: https://www.calt.iastate.edu/blogpost/2018-ushers-cuts-iowa-beginning-farmer-tax-credit-program

U.S. Department of Agriculture (USDA) Farm Service Agency (FSA). (2019a). Conservation Reserve Program monthly summary - May 2019. Retrieved from https://www.fsa.usda.gov/Assets/USDA-FSAPublic/usdafiles/Conservation/PDF/Summary\%202019\%20MAY.pdf

USDA FSA. (2019b). Conservation Reserve Program - Transition Incentives Program: Fact Sheet. Retrieved from https://www.fsa.usda.gov/Assets/USDA-FSAPublic/usdafiles/FactSheets/2019/crp transition incentive program-fact sheet.pdf

USDA National Agricultural Statistics Service (NASS). (2014). Beginning farmers—Characteristics of farmers by years on current farm (Report No. ACH12-5). Retrieved from https://www.nass.usda.gov/Publications/Highlights/2014/Beginning Farmers/index.php

USDA NASS. (2015). Farmland ownership and tenure. Retrieved from https://www.nass.usda.gov/Publications/Highlights/2015/TOTAL_Highlights.pdf

USDA NASS. (2019a). 2017 Census of Agriculture. Table 52. Selected Producer Characteristics: 2017 and 2012. Retrieved from https://www.nass.usda.gov/Publications/AgCensus/2017/Full Report/Volume 1, Chapter 1 US/st99 10052 0052.pdf

USDA NASS. (2019b). Farm producers: Revised census questions provide expanded demographic information. Retrieved from https://www.nass.usda.gov/Publications/Highlights/2019/2017Census Farm Producers.pdf

USDA Natural Resources Conservation Service (NRCS). (2018). Summary Report: 2015 National Resources Inventory. Washington, D.C.: USDA NRCS, and Ames: Center for Survey Statistics and Methodology, Iowa State University. Retrieved from https://www.nrcs.usda.gov/Internet/FSE DOCUMENTS/nrcseprd1422028.pdf

Valliant, J. C. D., Ruhf, K. Z., Dickinson, S. L., Zhang, Y., Golzarri-Arroyo, L., \& Farmer, J. R. (2020). Farm seeker needs versus farm owner offers: A comparison and analysis in the U.S. Midwest and Plains. Journal of Agriculture, Food Systems, and Community Development, 9(2), 141-157. https://doi.org/10.5304/jafscd.2020.092.006

Valliant, J. C. D., Ruhf, K. Z., Gibson, K. D., Brooks, J. R., \& Farmer, J. R. (2019). Fostering farm transfers from farm owners to unrelated, new farmers: A qualitative assessment of farm link services. Land Use Policy, 86, 438-447. https://doi.org/10.1016/j.landusepol.2019.05.004

Williamson, J. M., \& Girardi, A. G. (2016). Income tax credits to assist beginning farmers and ranchers: A look at state-level policies. Paper presented at the Annual meeting of the Agricultural and Applied Economics Association, Boston, Massachusetts. Retrieved from https://econpapers.repec.org/paper/agsaaea16/235810.htm

Williamson, J. M., \& Katchova, A. L. (2013). Tax-exempt bond financing for beginning and low-equity farmers: The case of 'Aggie Bonds.' Journal of Agricultural and Applied Economics, 45(3), 485-496. https://doi.org/10.1017/S1074070800005009

Zagata, L., \& Sutherland, L.-A. (2015). Deconstructing the 'young farmer problem in Europe': Towards a research agenda. Journal of Rural Studies, 38, 39-51. https://doi.org/10.1016/j.jrurstud.2015.01.003 